\title{
6. Sınıf Öğrencilerinin Dörtgenler Hakkındaki Geometrik Muhakeme Süreçleri ${ }^{1}$
}

\author{
DOI: $10.26466 /$ opus.673833 \\ * \\ Ahmet Mutluoğlu* - Ahmet Erdoğan** \\ * Öğretmen, Milli Eğitim Bakanlığı, Konya/Türkiye \\ E-Posta: mutluoglu.ahmet@gmail.com \\ ORCID: 0000-0003-0523-4490 \\ ** Prof. Dr., Necmettin Erbakan Üniversitesi/Ahmet Keleşoğlu Eğitim Fakültesi, Konya/Türkiye \\ E-Posta: aerdogan@erbakan.edu.tr \\ ORCID: $\underline{0000-0003-2024-4515}$
}

\section{Öz}

Bu çalışmanın amacı 6. sımı öğrencilerinin dörtgenler konusundaki geometrik muhakeme süreçlerinin Şekilsel Kavram Teorisi çerçevesinde incelenmesidir. Bu amaç doğrultusunda "öğrencilerin paralelkenar, dikdörtgen ve kare kavramları hakkında geometrik muhakeme süreçleri nasıldır?" problem cümlesine yanıt aranmıştır. Çalışmada nitel araştırma desenlerinden biri olan durum çalışması yöntemi kullanılmıştır. Araştırmanın çalışma grubu, Konya ili Kulu ilçe merkezinde bulunan bir ortaokulun 6 . sınıfında öğrenim görmekte olan 5 öğrenciden oluşmaktadır. Araştırmanın verileri yarı yapılandırılmış görüşme formu yaklaşımıyla elde edilmiştir. Ö̆̆grencilerle yapılan görüşmeler ses kaydına alınmıştır. Verilerin analizine başlanmadan önce görüşmeler araştırmacı-öğrenci diyalogu şeklinde metne dönüştürülüp analize hazır hâle getirilmiştir. Görüşme formundan elde edilen nitel veriler betimsel olarak analiz edilmiştir.

Araştırma bulgularına göre alt düzey başarıya sahip öğrencilerin geometrik muhakemelerinde çoğunlukla prototip şekil etkisinin baskın olduğu görülmüştür. Orta düzey ve üst düzey başarrya sahip öğrencilerin ise geometrik muhakemelerini çoğunlukla kavram kontrolünde yürütebildikleri, buna karşın zaman zaman prototip şekil etkisiyle de muhakeme yaptıkları belirlenmiştir. Ayrıca öğrencilerden verdikleri cevapların gerekçelerini ortaya koymaları istendiğinde geometrik şekillerin kavramsal yönüne daha fazla odaklanarak üst düzey geometrik muhakeme yapabildikleri saptanmıştır.

Anahtar Kelimeler: şekilsel kavram teorisi, geometrik muhakeme, üst düzey muhakeme

\footnotetext{
${ }^{1}$ Bu çalışma, birinci yazarın ikinci yazar danışmanlığında yürüttüğü doktora tezi çalışmasından üretilmiş-
} tir. 


\title{
6th Grade Students' Geometrical Reasoning Processes About Quadrilaterals
}

\begin{abstract}
The aim of this study is to examine the geometrical reasoning process of 6th grade students about quadrilaterals within the framework of the Theory of Figural Concepts. For this purpose, "How are the students' geometrical reasoning processes about parallelogram, rectangle and square concepts?" problem sentence was sought to answer. In the study, case study method, which is one of the qualitative research designs, was used. The study group consisted of 5 students studying in the 6th grade of a secondary school in Kulu district of Konya. The data of the study was obtained by semi-structured interview form approach. The interviews with the students were recorded. Before starting the analysis of the data, the interviews were translated into text in the form of researcher-student dialogue and made ready for analysis. The qualitative data obtained from the interview form were analyzed descriptively. According to the findings of the study, the prototype shape effect was dominant in the geometrical reasoning of the students with low level success. On the other hand, it was determined that students with intermediate and high level achievement could perform their geometrical reasoning mostly in conceptual control, but sometimes they also made reasoning with the effect of prototype shape. In addition, when the students were asked to provide justification for their answers, it was found that they were able to make high level geometric reasoning by focusing more on the conceptual aspect of geometric shapes.
\end{abstract}

Keywords: the theory of figural concepts, geometrical reasoning, high-level reasoning 


\section{Giriş}

Dünyada yaşanan hızlı değişim ve gelişmeler karşısında bireylerin matematiği günlük yaşamında kullanma ve anlama ihtiyacı da sürekli artmakta; matematiği anlayabilen ve matematik yapabilen bireyler geleceği şekillendirme noktasında daha fazla seçeneğe sahip olabilmektedir (Altun, 2007; MEB; 2009). Bu sebeple okullarda matematiğin öğrenilmesininöğretilmesinin her geçen gün daha önemli hâle geldiği söylenebilir.

Dünyadaki gelişmelere paralel olarak ülkemizde Milli Eğitim Bakanlığ1 (MEB) tarafından ilköğretim matematik dersi öğretim programı eski öğretim programlarından oldukça farklı bir biçimle çağdaş öğrenme yaklaşımları benimsenerek (Ersoy, 2006; Olkun ve Uçar, 2014) 2004-2005 eğitim öğretim yılında pilot olarak uygulamaya konulmuştur. Bu kapsamda, öğrenmeyi gözlemlenebilir davranışlar üzerinden açıklayan "davranışçı yaklaşım" paradigmasından vazgeçilmiş ve öğrenmeyi bilişsel süreçler perspektifinden ele alan öğrenme yaklaşımları benimsenmiştir (Ersoy, 2006). O günden günümüze kadar geçen sürede yenilenen matematik dersi öğretim programlarının (MEB, 2013; 2018) öğrenmeye-öğretmeye yönelik yaklaşımları ve oturduğu temel felsefe incelendiğinde bu yönelimin etkileri doğrultusunda yapılandırıldıkları görülmektedir. Eğitimde benimsenen bu yeni paradigmaya göre öğrenme, öğrencinin bir takım zihinsel ve fiziksel eylemler üzerine yaptığı muhakemeler neticesinde zihninde bilgiyi yapılandırmasıyla gerçekleşmektedir. Nitekim öğrenmenin en üst düzeye çıkabilmesi için okullarda öğrencilerin matematiksel düşünme ve muhakeme (akıl yürütme) süreçlerine odaklanılması gerekmektedir (NCTM, 2012).

Matematiğin muhtemelen en çok sezgiye dayall, en somut özelliklerine sahip ve gerçekle ilişkisini kuran geometri, içinde yaşadığımız evreni anlamayı, onu tanımlamayı ve çevremizle etkileşim kurmayı sağlayan bir dalıdır (Güven ve Öztürk, 2014). Ancak öğrenciler, bu alandaki kavramları anlamada zorlanabilmekte ve bu konudaki bilgilerin kavramsal boyutunun yeterli düzeyde ele alınmamasından birtakım kavram yanılgılarına sahip olabilmektedir (Erdogan, 2017a; Yenilmez ve Yaşa, 2008). Bu da öğrencilerin bilgiyi anlamlı bir şekilde değil de ezbere kullanma yolunu tercih etmelerine sebep olabilmektedir (Gülkılık, 2013, Erdogan, 2017a; Erdogan, 2017b).

Alan yazında yapılan araştırmalar, matematiğin diğer dallarında olduğu gibi geometride de öğrencilerin farklı düşünme biçimlerine ve farklı anlama 
düzeylerine sahip olduğunu ortaya koymaktadır (Baki, 2018). Bununla birlikte tüm bireylerin geometri bağlamlarında düşünebilme ve akıl yürütme (muhakeme) becerilerini geliştirebilme potansiyeline sahip olduğu da ifade edilmektedir (Van De Walle, Karp ve Bay-Williams, 2012). Geometrinin öğrenilmesi-öğretilmesi üzerine yapılan birçok araştırmaya bakıldığında da geometrik muhakemenin (GM) doğası ve nasıl geliştirilebileceği üzerinde durulduğu görülmektedir (Güven ve Karpuz, 2016; Jones, 1998; Karpuz, Koparan ve Güven, 2014). Örneğin Van Hiele'nin geometrik düşünce düzeyleri modelinde (1959), öğrencilerin geometriyi anlamaları, giderek soyutlama düzeyinin arttğı beş hiyerarşik düzeyde açılanmaktadır (Van De Walle vd., 2012). Bu modelde öğrencilerin düzeylerde ilerlemesi, kesin olarak belirli bir yaşa erişerek değil, daha çok öğrencilerin aldıkları eğitime bağlı olarak edindikleri tecrübeler temelinde gerçekleşmektedir (Van Hiele, 1999. Akt: Breyfogle ve Lynch, 2010). Bu çalışmalardan bir diğeri de Fischbein (1993)'in ortaya koyduğu Şekilsel Kavram Teorisi'dir.

Geometrik şekiller üzerinde muhakeme sürecini ele alan Fischbein (1993) teorisinde, öğrencilerin zihinlerinde geometrik bir şeklin kavram ve şekil boyutlarının birbiriyle etkileşimli bir yapıda oluşturulması sürecinin rutin geometri derslerinin doğal bir sonucu olarak değerlendirilmemesi gerektiğini vurgulamaktadır. Nitekim etkili ve anlamlı bir geometri öğrenmeöğretme sürecinin gerçekleşmesinin ancak alan yazında GM'yi ele alan yaklaşımlar perspektifinde yapılandırılmış öğrenme ortamlarının tasarlanmasıyla mümkün olabileceği ifade edilmektedir (Güven ve Karpuz, 2016; Mariotti ve Fischbein, 1997). Okul ve okul dışı yaşamın kolaylaştırılmasında önemli bir etkiye sahip olan muhakeme becerisinin geliştirilmesi için okulda uygun ortamların hazırlanmasının gerektiği matematik dersi öğretim programlarında da üzerinde durulan bir kavramdır (MEB, 2013). Bu doğrultuda programda muhakeme becerisinin gelişimi sürecinde öğrencilere, bir kavram üzerinde yaptı̆̆ çıarımların doğruluğunu ve geçerliliğini savunması, mantıklı genellemelerde ve çıkarımlarda bulunması vb. imkânların verilmesi gerektiği vurgulanmaktadır (MEB, 2013).

Alan yazında, geometrinin nasıl anlaşılabileceğini ve geometrik muhakeme becerisinin nasıl geliştirilebileceğini açıklamaya çalışan bazı teorilerden yukarıda bahsedilmiştir. Alan yazında ortaya konulmuş farklı teorileri değerlendiren çalışmalarda (Baki, 2018; Güven ve Karpuz, 2016; Jones, 1998; Olivera ve Zeljić, 2017; Paksu Duatepe, 2016; Van De Walle vd., 2012) bazı 
teorilerin sıklıkla ön plana çıktı̆̆ 1 görülmektedir. Yapılan birçok bilimsel araştırmada da (örn. Fujita, 2012; Karpuz, 2018; Karpuz vd., 2014; Ubuz, 2017) skklıkla bu teorilere başvurulduğu görülmektedir. Bu teoriler incelendiğinde geometride anlamayı bir kısmının gelişimsel bir perspektiften (örn. Van Hiele Geometrik Düşünce Düzeyleri, 1959) bir kısmının da bilişsel perspektiften (örn. Fischbein'in Şekilsel Kavram Teorisi, 1993; Duval'in Bilişsel Modeli, 1998) değerlendirdiği görülmektedir (Güven ve Karpuz, 2016).

Bundan sonraki bölümde, çalışmanın kuramsal temelini oluşturması bakımından yalnız Fischbein (1993)'in "Şekilsel Kavram Teorisi" üzerinde durulmuştur.

\section{Fischbein'in Şekilsel Kavram Teorisi}

Kavram, genellikle nesnelerin veya olayların ait olduğu sınıfının soyut ve genel bir temsili (bir fikri) olarak; imge (özellikle görsel bir imge) ise bir nesnenin veya olayın duyusal bir temsili olarak tanımlanmaktadır (Fischbein ve Nachlieli, 1998). Bilişsel psikolojide kavram ve imge birbirinden tamamen ayrık ve zihinsel etkinlikler sırasında etkileşime girmelerine rağmen iki ayrı kategori olarak kabul edilmektedir. Çünkü kavram uzamsal özelliklere sahip olmayı idealdir ve soyuttur. İmge ise duyusal özellikleri nedeniyle bir fikre indirgenemez yapıdadır (Fischbein ve Nachlieli, 1998). Örneğin bir kavram olarak masa soyut olup tüm masaların ortak özelliklerini ihtiva eden zihinsel bir yapıyı temsil ederken zihnimizdeki masa imgesi somut olup içinde öznel öğeler ihtiva eder. Nitekim zihnimizde dört ayaklı bir masa imgesine sahip olabiliriz ancak bu özelliğin kavram olarak masada olma zorunluluğu yoktur (Güven ve Karpuz, 2016).

Fischbein (1993) bilişsel psikolojideki şekil ile kavram ayrımının geometrik şekillerde geçerli olmadığını, geometrik şekillerin iki kategoriye eş zamanlı olarak (aynı anda) sahip zihinsel varlıklar olduğunu ifade etmektedir. Bu sebeple Fischbein (1993) geometrik şekillerin üçüncü bir kategori oluşturduğunu ifade ederek teorisine de adını veren 'Şekilsel Kavram' terimini geliştirmiştir. Bu şekilde bir geometrik şeklin yalnız kavrama ya da şekle indirgenemeyecek türden bir zihinsel varlık olduğu vurgulanmıştır. Örneğin bir düzlem üzerine çizilmiş herhangi bir üçgen, görüntü olarak zihinsel imgeyi (şekli) temsil ederken sahip olduğu özellikleri bakımından (iç açı ölçüleri toplamının $180^{\circ}$ olması gibi) aynı zamanda kavramı da temsil et- 
mektedir. Fischbein (1993) geometrik şekillerin sahip olduğu bu çift yönlü özelliği aşağıda verilen örnek üzerinden açıklamaya çalışmıştır.

İkizkenar bir ABC üçgeninde (Şekil 1) AB kenarı ile AC kenarının uzunluğu eşit olsun. $B u$ durumda birisinin $B$ ve $C$ açlarının ölçülerinin eşitliğini aşağıdaki gibi kanıtladığını düşünelim:

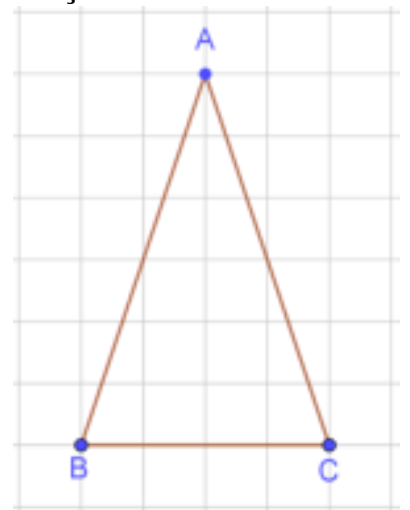

Şekil 1. ABC İkizkenar Üçgeni

$A B C$ üçgenini kendisinden ayırıp AC kenarı sol tarafta ve $A B$ kenarı sağ tarafta olacak şekildeki ters çevrilmiş hâli, orijinal şekille üst üste gelecek şekilde çakıştııılsın. Bu durumda $A$ açısı aynen kalırken $A B$ ve $A C$ kenarları aynı uzunluğa sahip olduğundan sol tarafta $A C$ kenarı ile $A B$ kenarı, sağ tarafta ise $A B$ kenarı ile $A C$ kenarı tam olarak çakışır. Böylece $A B C$ üçgeni ile ters çevrilmiş hâlinin tam olarak çakıştığı görülebilir. Sonuç olarak B açısının ölçüsünün $C$ açısının ölçüsüne eşit olduğu gösterilmiş olur.

$\mathrm{Bu}$ ispat sürecinde kavramsal bilgi olarak ifade edilen bir kısım bilgilerin (nokta, açı, üçgen, AB ve AC kenarlarının eşit uzunlukta olması gibi) kullanıldığı görülmektedir. Fakat şekil bilgisi ve şekilsel olarak temsil edilen işlemler de (ABC üçgenini kendisinden ayırma, tersine çevirme ve orijinali ile çakıştırma gibi) bu süreçte eş zamanlı olarak kullanılmıştır. Görüldüğü üzere ispat sürecinde şekiller ve kavramlar iç içe geçmiş bir vaziyette birbiriyle uyumlu bir şekilde işe koşulmuştur. Peki, burada birbirinden bağımsız iki varlığın (şekil ve kavram) bir karışımından mı bahsedilmektedir? İspatın özü olan ABC üçgeninin kendinden ayrilıp ters çevrilmesi işlemi üzerinden bu soruya bir yanıt verilmiştir. 
Bilindiği gibi kavramlar kendinden ayrılamazlar, ters çevrilemezler ve çakıştırılamazlar. Gerçekte (duyularla algıladığımız gerçeklik) bir nesneyi kendinden ayırmak mümkün olmadığından böyle bir işlemin somut bir anlamı (gerçeklikle bir ilgisi) yoktur (Fischbein, 1993). Bu durumda ideal bir dünyada ideal nesneler ile işlemler yapılmıştır (Fischbein, 1993. Akt: Güven ve Karpuz, 2016). Burada bahsi geçen nesneler (noktalar, kenarlar, açlar ve onlarla yapılan işlemler) sadece ideal bir varlıktır. Yani nesneler kavramsal bir niteliğe sahiptir. Ama aynı zamanda bu nesneler doğası gereği özünde birer şekildir: sadece görüntüye dayanarak ayırma, ters çevirme ya da çakıştırma gibi işlemler yapılabilir. O zaman idealize edilmiş dünyada geometrik şekillerin var olması ve üzerinde bir takım işlemlerin gerçekleştirilebilmesi onların ancak eş zamanlı olarak kavramsal ve uzamsal özelliklere sahip zihinsel varlıklar olduğunun kabul edilmesiyle mümkün olabilir (Fischbein, 1993). Bu durumda yukarıda ele alınan örnekte, bir üçgenin ve öğelerinin tek başına bir kavram ya da sadece görüntüden ibaret olduğu düşünülemez (Fischbein ve Nachlieli, 1998).

\section{Şekilsel Kavram Teorisine Göre Geometrik Muhakeme}

Şekilsel Kavram Teorisi'ne göre GM'nin yapısı kavram-şekil ilişkisinin niteliği ile ilgilidir. İdealde şeklin anlamlarını, ilişkilerini ve özelliklerini kontrol etmesi gereken bileşen kesinlikle kavram olmalıdır (Fischbein, 1993). Bu da GM sürecinde üst düzey muhakeme (ÜGM) olarak değerlendirilmektedir. Ancak muhakeme sürecinde şeklin kavram üzerinde baskın olduğu durumlar da söz konusu olabilmektedir. Bunun ise çözüm adımlarının mantıksal tutarlılığının ve sonuçtan genellemelere ulaşılmasını sağlayan geometrinin tümdengelimli yapısının eksik kalmasına sebep olduğu ifade edilmektedir (Fischbein, 1993. Akt: Güven ve Karpuz, 2016).

Fischbein (1993) birçok öğrencinin geometrik bir şekli şekilsel kavram olarak kabul etmemelerine özel temsiller üzerindeki çalışmalarından edindikleri deneyimlerin etkisinin sebep olduğunu ifade etmektedir. Bu durum geometrik şeklin imajının kavramsal tanım üzerinde sahip olduğu baskın etkisi olarak açıklanmaktadır. Örneğin bir öğrenci dikdörtgenin tanımını biliyor olsa bile karenin ve kare formunda verilmeyen bir dikdörtgenin yalnız görünüşlerine bakarak (şeklin kavram üzerindeki baskın kontrolü) ikisi arasındaki hiyerarşik ilişkiyi belirleyemeyecektir (Fischbein, 1993). Ancak 
öğrenci, verilen şekilleri aynı zamanda kavramsal bir bakış açısıyla ele aldığında karenin de bir dikdörtgen olduğunu kavrayabilecektir.

Bunun yanında (gelişimsel yaklaşımın aksine) özellikle geometride keşif ya da bir teoremin ispatı sürecinde ihtiyaç duyulabilecek sezgi boyutunun geometrik bir şeklin kavramsal yönünden çok şekilsel yönü ile ilgili olduğu bilinmektedir (Fischbein, 1993). Çünkü geometrik kavramları öncelikle sezgisel olarak algılar, daha sonra matematikleştirerek anlamlandırırız (Baki, 2018). Bu sebeple yalnız kavram kontrolünde gerçekleştirilen bir muhakemede, problemlerin çözümünde veya bir önermenin ispatında gerekli olabilecek sezgi ve keşif boyutları eksik kalacaktır (Güven ve Karpuz, 2016). Çünkü sürekli olarak teorem ve tanım gibi analitik ve formel gerekçelere (kavrama) dayandırılan bir muhakemede üretken fikirlerin akışı bozulabilmekte ve hatta engellenebilmektedir (Fischbein, 1993). Bu sebeple GM sürecinde şekil ile kavram etkileşim içerisinde olması gerekmektedir.

Öğrencilerin GM'lerinde yaptıkları birçok hataya, şekilsel kavramların kavramsal ve şekilsel yönleri arasındaki bölünme (veya uyum eksikliği) sebep olmaktadır (Fischbein, 1993). Hâlbuki şekilsel kavram, sadece şekil ya da sadece kavrama indirgenemeyecek zihinsel bir varlığı işaret eder (Fischbein, 1993). Bununla birlikte şekiller ve kavramlar, kişinin bilişsel aktivitesinde bazen birbiriyle etkileşime girerken bazen de çatışabilir. Şekilsel kavramın gelişimi ise genellikle doğal bir süreç değildir. Dolayısıyla geometrinin okul programlarında bu kadar zor bir konu olmasının ana nedenlerinden biri şekilsel kavramların doğal bir süreçte ideal biçimlerine doğru gelişim sergilememesidir. Bu sebeple matematik eğitiminin temel görevlerinden biri (geometri alanında), bütüncül bir zihinsel nesne hâline gelene kadar, geometrik şeklin sahip olduğu iki yön arasında sıkı bir işbirliğinin kurulmasını sağlayacak öğretim durumlarının oluşturulmasıdır (Fischbein, 1993).

Öğrenciler, geometri ve ölçme öğrenme alanındaki kavramları anlamada zorlanabilmekte ve birtakım kavram yanılgılarına sahip olabilmektedir. Bu durumun bir sonucu olarak öğrenciler bilgiyi anlamlı bir şekilde öğrenmek yerine ezberleme yoluna giderek kullanmayı tercih etmektedir (Gülkılık, 2013). Buradan hareketle öğrencilerin mevcut GM süreçlerinin irdelenerek durumlarının ortaya konulmasının önemli olduğu düşünülmektedir.

$\mathrm{Bu}$ çalışmanın amacı da 6. sınıf öğrencilerinin dörtgenler konusundaki GM süreçlerinin Fischbein (1993)'in “Şekilsel Kavram Teorisi”" çerçevesinde 
incelenmesidir. $\mathrm{Bu}$ amaç doğrultusunda "Öğrencilerin paralelkenar, dikdörtgen ve kare kavramları hakkında geometrik muhakeme süreçleri nasıldır?" problem cümlesine yanıt aranmıştır.

\section{Yöntem}

$\mathrm{Bu}$ araştırmada ortaokul 6. sinıf matematik dersi dörtgenler konusunda öğrencilerin GM süreçlerinin incelenmesi amacıyla nitel araştırma desenlerinden biri olan durum çalışması yöntemlerinden "İç içe geçmiş tekli-durum tasarımı" kullanılmıştır.

Bu tasarımda, tek bir durum içerisinde çoğu zaman birden çok alt tabaka ya da birim olabilir. Burada durumun bir bütün ya da tek bir analiz birimi olarak düşünülmesi yerine, durumu oluşturan alt birimlerin analiz ünitesi olarak kullanılması söz konusudur (Yıldırım ve Şimşek, 2008). Mevcut çalışmada da öğrencilerin (durum) GM süreçleri incelenirken farklı başarı düzeyindeki öğrenciler (alt tabakalar) olduğu dikkate alınarak "İç içe geçmiş tek durum deseni" kullanılmıştır.

\section{Çalışma Grubu}

Araştırmanın çalışma grubu, 2016-2017 eğitim-öğretim yılında Konya ili Kulu ilçe merkezinde bulunan bir ortaokulun 6. sınıfında öğrenim görmekte olan beş öğrenciden oluşmaktadır. Çalışma grubu, aynı şubede öğrenim görmekte olan öğrencilerin arasından tabakalı amaçsal örnekleme yaklaşımiyla belirlenmiştir.

Öğrenciler, görüşmeler öncesinde uygulanan başarı testinden elde ettikleri puanlara göre alt, orta ve üst olmak üzere 3 düzeye (tabakaya) ayrılmıştır. Ardından görüşmeye istekli olan öğrenciler arasından her düzeyden iki öğrenciyle görüşme gerçekleştirilmiştir. Ancak orta düzey başarıya sahip olan öğrencilerden biriyle yapılan görüşmede, öğrencinin görüşme formundaki sorulara kısa cevaplar vermesi ve birçoğunu "bilmiyorum" şeklinde yanıtlayarak isteksiz davranması sebebiyle öğrenciden sağlıklı analiz yapmaya elverişli veri elde edilememiştir. Dolayısıyla bu öğrencinin, GM sürecinin yeterli düzeyde anlaşılmasının mümkün olamayacağı düşüncesiyle çalışma grubuna dâhil edilmemesine karar verilmiştir. Sonuç olarak alt 
düzeyden iki (A1 ve A2), orta düzeyden bir (O1) ve üst düzeyden iki (Ü1 ve Ü2) olmak üzere toplam beş öğrenci çalışma grubu olarak belirlenmiştir.

\section{Veri Toplama Araçlan}

6. sınıf öğrencilerinin dörtgen kavramı (paralelkenar, dikdörtgen, kare özelinde) hakkındaki GM süreçlerini incelemek için araştırmacı tarafından yarı yapılandırılmış bir görüşme formu hazırlanmıştır. Öğrencilerle yapılan görüşmelerde kullanılan görüşme formunda dörtgenlerle ilgili sorulan sorular için kullanılan görsel Şekil 2' de verilmiştir.

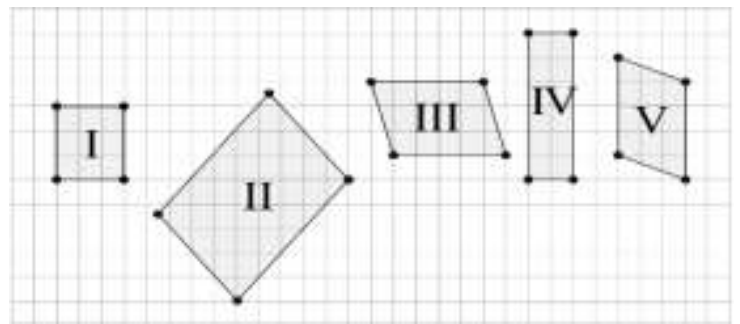

Şekil 2.Paralelkenar,Dikdörtgen ve Kare ile İlgili Görüşme Formunda Kullanılan Görsel

Gerçekleştirilen görüşmelerde formda yer alan dörtgenler üzerinden öğrencilere altışar tane soru yöneltilmiştir.

1. Yukarıda verilen dörtgenlerden hangisi (ya da hangileri) paralelkenardır?

2. Verilen dörtgenleri hangi özelliklerine göre sınıflandırdığınızı (paralelkenar olarak isimlendirdiğinizi) açıklayınız.

3. Yukarıda verilen dörtgenlerden hangisi (ya da hangileri) dikdörtgendir?

4. Verilen dörtgeni hangi özelliklerine göre sınıflandırdığınızı (dikdörtgen olarak isimlendirdiğinizi) açılayınız.

5. Yukarıda verilen dörtgenlerden hangisi (ya da hangileri) karedir?

6. Verilen dörtgeni hangi özelliklerine göre sınıflandırdığınızı (kare olarak isimlendirdiğinizi) açılayınız.

1, 3 ve 5 numaralı sorularda öğrencilerden herhangi bir gerekçe ortaya koymadan verilen şekilleri paralelkenar, dikdörtgen ve kare olarak sınıflandırmaları; 2, 4 ve 6 numaralı sorularda ise öğrencilerin GM süreçlerini irdelenmek amacıyla yaptıkları sınıflamaların gerekçelerini ortaya koymaları istenmiştir. 
Formdaki sorular, öğrencilerin geometrik kavramları ele almadaki muhakeme süreçlerini incelemek için "Şekilsel Kavram Teorisi" çerçevesi dikkate alınarak hazırlanmıştır. Ayrıca üzerinde çalışılacak dörtgenlerin belirlenmesi noktasında Ortaokul Matematik Dersi Öğretim Programı (MEB, 2013) temel alınmıştır. Formdaki sorular, öğrencilerin gerçekleştirdikleri muhakemelerde şekillerin şekilsel ve kavramsal boyutları arasında kurdukları etkileşimin niteliğini irdelemeye elverişli olacak şekilde hazırlanmıştır. Görüşme formunda, bazı öğrencilerin yaptıkları açıklamaları netleştirmek ve GM süreçlerini daha iyi irdelemek için hem formda yer alan hem de görüşmenin akışına göre formda yer almayan sonda sorular da (toplam on iki adet) kullanılmıştır. Sorular ve formun yapısı ile ilgili matematik eğitimi alanında uzman bir akademisyenin görüşüne başvurulmuş ve gerekli düzenlemeler yapılarak form uygulanmaya hazır hâle getirilmiştir.

\section{Verilerin Toplanması}

Araştırmacı tarafından, GM süreçlerini irdelemek üzere beş öğrenci ile görüşme formu yardımıyla yarı yapılandırılmış görüşmeler gerçekleştirilmiştir. Görüşmelerde ele alınan sorular öğrencilere yazılı formlar şeklinde sunulmuştur. Öğrencilerden formda yer alan soruları sesli olarak okuyarak cevaplandırmaları ve formda ilgili kısımları doldurmaları istenmiştir. Öğrencilerle yapılan görüşmelerin tamamı ses kaydına alınmıştır.

\section{Verilerin Analizi}

Görüşmelerden elde edilen ses kayıtları öncelikle araştırmacı-öğrenci diyalogu şeklinde metne dönüştürülerek veri analizine hazır hâle getirilmiştir. Ardından veriler betimsel analizinden yararlanılarak çözümlenmiştir.

Betimsel analizde dört aşama söz konusudur. Bunlar: 1. Çerçeve oluşturma, 2. Çerçeveye göre verilerin işlenmesi 3. Bulguların tanımlanması, 4. Bulguların yorumlanması şeklindedir (Yıldırım ve Şimşek, 2008). Bu araştırmada da söz konusu aşamaların ele alınış biçimi aşağıda özetlenmiştir:

1. Verilerinin analizinde yarı yapılandırılmış görüşme formundaki sorular ve Fischbein (1993)'in "Şekilsel Kavram Teorisi" bir çerçeve olarak belirlenmiştir. 
2. Belirlenen çerçeve doğrultusunda elde edilen veriler, formda yer alan sorular altında bir araya getirilmiş. Her soru için katılımcıların verdikleri yanıtlar analiz edilmiştir. Bu aşamada sonuçların yazımında ilave olarak sıklıkla doğrudan alıntılara yer verilmiştir.

3. Elde edilen bulgular Fischbein (1993)'in "Şekilsel Kavram Teorisi'ne" göre tanımlanmıştır. Bu aşamada doğrudan alıntılarla tanımlamalar desteklenmiştir.

4. Son aşamada bulgulara ilişkin açıklamalar ve anlamlandırmalar yapılmıştır. Yine bu aşamada farklı başarı düzeyindeki öğrencilerin GM süreçleri arasında karşılaştırmalar yapılmıştır.

Bir araştırmada geçerliliğin sağlanması için verilerin ve sonuçların nasıl elde edildiği ayrıntılı bir şekilde açıklanmalıdır. Betimsel bir analizde doğrudan alıntılara yer verilmesi ve bu alıntılardan yola çkarak sonuçlara ulaşılması araştırmanın geçerliliğinin önemli göstergeleri olarak değerlendirilmektedir (Yıldırım ve Şimşek, 2008). Bu araştırmada da verilerin nasıl elde edildiği ve sonuçlara nasıl ulaşıldığı ayrıntılarıyla açıklanmış, bulgu ve sonuçların elde edilmesinde sıklıkla doğrudan alıntılara yer verilmiştir.

Nitel bir araştırmada "araştırmanın her bir aşamasının ve izlenen yolun detaylı olarak tanımlanması" araştırmanın güvenirliğini arttıran bir yol olarak ifade edilmektedir (Büyüköztürk, Çakmak, Akgün, Karadeniz ve Demirel, 2017). Büyüköztürk vd. (2017)'ne göre görüşmelere ait ses kayıtlarının alınması, fotoğraf çekilmesi, katılımcı alıntılarına doğrudan yer verilmesi yine araştırma güvenirliğini arttıran unsurlardır. Bunlara ilave olarak verilerin analizinde tutarlılığın sağlanmasının güvenirliği arttırdığı bilinmektedir (Yıldırım ve Şimşek, 2008). Bu araştırmada da güvenirliği sağlamak için araştırmanın tüm aşamaları detaylı biçimde açklanmış, verilerin elde edildiği görüşmelerin ses kaydı alınmış ve verilerin analizleri bu alanda tecrübesi olan bir akademisyen tarafından kontrol edilmiştir. Bu süreçte araştırmacının kendisi ile akademisyenin görüş birliğine vardığı ve görüş ayrilığ1 yaşadığı durumlar tespit edilmiştir. Ardından Miles ve Huberman (1994)'ın güvenirlik için önerdiği formül (Güvenirlik = Görüş Birliği / [Görüş Birliği + Görüş Ayrılığı]) kullanılarak uyum yüzdesi hesaplanmıştır. Buradan, araştırma verilerinin analizindeki uyum yüzdesinin (güvenirlik) \%90 olduğu belirlenmiştir. 


\section{Bulgular}

$\mathrm{Bu}$ bölümde, araştırmanın problemi çerçevesinde toplanan nitel verilerin çözümlenmesi sonucu elde edilen bulgular ve bu bulgulara ilişkin yorumlar yer almaktadır.

Görüşme formundaki sorulardan her bir öğrenci için elde edilen bulgular, geometrik şekillere göre düzenlenerek aşağıda başliklar hâlinde sunulmuştur. Her bir başlıktan sonra verilen tabloda öğrencilerin, şekillerle ilgili kendilerine yöneltilen sorular üzerine yürüttükleri muhakemeler neticesinde şekilleri nasıl sınıflandırdıkları özetlenmiştir.

\section{Paralelkenar}

Öğrencilerin paralelkenarla ilgili kendilerine yöneltilen ilk iki soru üzerine yürüttükleri muhakemeler neticesinde kaç numaralı şekilleri paralelkenar olarak sınıflandırdıkları Tablo 1'de verilmiştir.

Tablo 1. Öğrencilerin paralelkenarla ilgili sorulan sorulara verdikleri yanıtlar

\begin{tabular}{lll}
\hline Öğrenci & 1. Soru & 2. Soru \\
\hline U11 & III- V & I-II-III-IV-V \\
\hline Ü2 & I-II-III-IV-V & I-II-III-IV-V \\
\hline O1 & I-II-III-IV-V & I-II-III-IV-V \\
\hline A1 & II-III-V & II-III-V \\
\hline A2 & II-III-V & II-III-V \\
\hline
\end{tabular}

Ü1, ilk soruya verdiği cevapta yalnız prototip (geometrik şekillerin sıklıkla kullanılan, genellikle en uzun özellik listesine sahip ve sık rastlanan şekilsel görünümleri (Hershkowitz, 1990: 82. Akt: Türnüklü, 2014).) olarak verilmiş paralelkenarları (III ve V) doğru olarak tespit edebilmiştir. Öğrencinin prototip olmayan paralelkenarlar hakkında gerçekleştirdiği GM'si irdelendiğinde şekillerin bu halleriyle paralelkenar olmadığını ancak açı ve kenarlarının manipüle edilerek paralelkenara dönüştürülebileceğini ifade etmiştir (Aslında hepsini paralelkenar yapabiliriz ama bu şekilde (mevcut hâlleriyle) düşünürsek paralelkenar olmuyor.). Bu bulgulardan öğrencinin GM sürecine baskın olarak prototip şeklin etki ettiği görülmüştür. Buna karşın yapılan görüşmede öğrencinin paralelkenarın belirleyici olan özelliklerini eksiksiz olarak bildiği de ortaya çıkmıştır. Nitekim öğrenci, bir dörtgenin hangi özel- 
likleri sağlaması durumunda paralelkenar olacağı sorusuna "karşılıklı kenarları birbirine paralel", "Karşıllklı olan çapraz açıları birbirine eş" ve formdaki bir paralelkenar üzerinde karşılıklı kenarları göstererek "hocam mesela bu 50 ise bu da 50'dir" cevabını vermiştir.

Görüşmenin devamında öğrenciden bu özelliklerin prototip olmayan paralelkenarlar tarafından sağlanıp sağlanmadığını belirlemesi istenmiştir. Öğrenci daha sonra IV numaralı şekil için "karşıllkhı kenarları eşit ve paralel", II numaralı şekil için "dikdörtgen de aynı özellikleri taşıyor" ve I numaralı şekil için "kare de oluyor" gerekçeleriyle bu şekillerin de paralelkenarın tüm özelliklerini taşıdığını ve bunların da paralelkenar olduğunu belirtmiştir. Yani öğrenciye yöneltilen ilave soru neticesinde öğrenci, geometrik şekiller üzerinde bu sefer kavram kontrolünde GM yaparak tümünün paralelkenar olduğuna karar vermiştir. Buradan öğrencinin GM sürecinde şeklin kavramsal yönünü de dikkate almasını gerektirecek sorularla karşılaşmasının kavram kontrolünde GM yapması yönünde teşvik edici olduğu görülmüştür. Bu durumda Ü1'in, her ne kadar matematik dilini etkin olarak kullanamıyor olsa da paralelkenar özelinde ÜGM gerçekleştirebildiği anlaşılmıştir.

O1 ve Ü2, tüm şekillerin paralelkenar sınıfına ait olduğunu doğru olarak belirleyebilmiştir. Öğrencilerin şekiller hakkında verdikleri kararların gerekçeleri sorgulandığında bu şekillerin paralelkenarın özelliklerini sağlayıp sağlamadıklarını irdeledikleri ve bu süreçte yaptıkları GM'ler neticesinde verdikleri kararların doğruluğunu teyit edebildikleri görülmüştür.

O1 ve Ü2'ye paralelkenarın özelliklerinin ne olduğu sorulduğunda Ü2 "karşıllklı kenarları eş ve paralel ve karşıllklı açıları eştir.", O1 ise "Karşılıklı kenarları birbirine paraleldir. Karşılıkl kenarları uzunluklar birbirine eşittir. Hocam karşıllkh açıları da birbirine eşittir." yanıtını vermiştir. Buradan bu öğrencilerin paralelkenar hakkındaki kavramsal bilgilerinin yeterli düzeyde olduğu anlaşılmıştır. Daha sonra bu bilgilerini GM sürecinde ne denli etkili kullanabildiklerini anlamak için Ü2'ye görüşme formunda yer almayan "Peki, aşağıya (form üzerinde kareli zemine) bir tane III numarah şekle benzer, bir tane dikdörtgen ve bir tane kare çizsen üç paralelkenar çizmiş olur musun ?" sorusu yöneltilmiş ve öğrenci de bu soruya "evet" yanıtını vermiştir. O1'e ise kare ve dikdörtgenin paralelkenarın özel bir durumu olup olmadığı sorulduğunda öğrenci "Evet hocam. Sağladıkları özelliklerden diyebiliyorum." şeklinde cevap vermiştir. Buradan öğrencilerin GM'lerini yalnız şekil etkisiyle değil 
aynı zamanda kavram kontrolünde de ele alabildikleri anlaşılmıştır. Öğrencilerin prototip olan ve olmayan tüm şekillerde, şekil - kavram etkileşiminde sürecin kavram kontrolünde yürütülmesinden paralelkenar özelinde ÜGM gerçekleştirebildikleri anlaşılmıştır. Nitekim bu öğrencilere şekil verilmeden yalnız sözlü olarak paralelkenarın özel durumlarının (dikdörtgen, kare) da bir paralelkenar olup olmadığı sorulduğunda, yaptıkları GM'nin kavram kontrolünde gerçekleştiği teyit edilerek anlaşılmıştır.

Yukarıdaki bulguların aksine Ü2'ye yöneltilen bir soruda GM'sini şeklin baskın etkisinde gerçekleştirdiği de görülmüştür. Öğrenciye herhangi bir çizim içermeyen "dikdörtgende olup da paralelkenarda olmayan bir özellik var mıdır?" sorusu yöneltildiğinde öğrenci "dikdörtgenin açılarının hepsi eşit ama paralelkenarın açıları farklı" yanıtını vermiştir. Öğrencinin bu soru üzerine yürüttüğü GM'nin prototip şekil etkisiyle gerçekleştiği anlaşılmıştır. Nitekim öğrenci, bir paralelkenarın da tüm iç açılarının eş olabileceği durumunu göz ardı etmiştir. Bu ve daha önceki bulgulardan Ü2'nin paralelkenar özelinde GM sürecinde zaman zaman prototip şekil etkisinde kalabildiği ancak kavram etkisinin çoğunlukla baskın olduğu anlaşılmıştır.

A1 ve A2, verilen beş şekil de paralelkenar olmasına karşın yalnız prototip olarak verilenleri (II, III ve V) tespit edebilmiştir. Öğrencilerin prototip olmayan paralelkenarlar hakkında verdikleri kararların gerekçeleri sorgulandığında bu şekillerin paralelkenarın özelliklerini sağladığını kısmen tespit edebildikleri, buna karşın bu şekilleri paralelkenar olarak değerlendiremedikleri görülmüştür.

A1'e paralelkenarın özelliklerinin ne olduğu sorulduğunda öğrenci "karşılıklı kenar uzunlukları aynı" ve karşıılıklı açıları ("çapraz açıları") eş yanıtını verdikten sonra bu özelliklerin III numaralı şekil tarafından sağladığını belirtmiştir. Ancak öğrenci I ve IV numaralı şekillerin paralelkenarın özelliklerini sağlamış olduğunu tespit edebilmiş olmasına rağmen kendisine yöneltilen "O hâlde bu şekle (IV numaralı şekil) aynı zamanda bir paralelkenardır denilebilir mi?" sorusuna "Hayır hocam yanlış derim." şeklinde yant vermiştir. Yani öğrenci dikdörtgeni, paralelkenarın özel bir durumu olarak değerlendirememiştir. Benzer şekilde öğrenciye "Peki, kare için ne düşünüyorsun? (Paralelkenarm özelliklerin sorgularken. Öğrenci I. şekil için daha önce kare ifadesini kullandiğı için araştırmacı da "kare" ifadesini kullanmıştır.)" sorusu yöneltildiğinde öğrenci "Kare için aynı şekilde. Karşılıklı kenarları eşit, açıları eşit vs." şeklinde yanıt vermiş ancak karenin paralelkenarla olan ilişkisini kuramamıştır. 
Benzer şekilde A2'ye paralelkenara ait özelliklerin, IV numaralı şekil tarafından sağlanıp sağlanmadığı sorulduğunda öğrenciden "Karşıllklı kenarları eşittir hocam. Karşıllklı kenarları da birbirine paralele benziyor." yanıtı alınmıştır. Buna mukabil öğrenciye "O hâlde bu şekil bir paralelkenar mıdır?" diye sorulduğunda öğrenci "Yok hocam" yanıtını vermiştir. Ayrıca öğrenciye "bu paralelkenarda eş olan açlar var mı? (V. şekil gösterilerek.)" sorusu yöneltildiğinde öğrenciden "Yok hocam." yanıtı alınmıştır. Öğrenci daha öncesinde V numaralı şeklin paralelkenar olduğunu doğru tespit edebilmiş olmasına rağmen paralelkenarın karşılıklı açılarının eş olma özelliğini şekil üzerinde ifade edememiştir. Bu durum öğrencinin GM sürecinde verilen şeklin paralelkenar olup olmadığına karar vermede şeklin kavramsal boyutunu yeterince göz önünde bulundurmayıp prototip şekil etkisiyle karar verdiğine işaret etmektedir. Nitekim öğrenciye paralelkenarın özelliklerini ifade etmesi istendiğinde öğrenci zihnindeki prototip (model) paralelkenarı "(III. $n u$ maralı şekli göstererek) Böyle mesela hah gibi yatan." ifadesiyle açıklamıştır.

Yukarıdaki bulgulardan A1 ve A2'nin GM süreçlerinde kavramın şekli etkili biçimde yönetemediği anlaşılmıştır. Öğrencilerin, dikdörtgenin paralelkenarın özelliklerini sağlasa bile onun bir paralelkenar olmadığını ifade etmeleri prototip şekil etkisinin bariz bir göstergesi olarak değerlendirilmiştir. Sonuç olarak şekil-kavram etkileşiminde kavramın etkisinin yeterli düzeyde olamadığı ve öğrencilerin ÜGM gerçekleştiremediği anlaşılmıştır.

\section{Dikdörtgen}

Öğrencilerin dikdörtgenle ilgili kendilerine yöneltilen üçüncü ve dördüncü soru üzerine yürüttükleri muhakemeler neticesinde kaç numaralı şekilleri dikdörtgen olarak sınıflandırdıkları Tablo 2' de verilmiştir.

Tablo 2. Öğrencilerin dikdörtgenle ilgili sorulan sorulara verdikleri yanıtlar

\begin{tabular}{lll}
\hline Ögrenci & 3. Soru & 4. Soru \\
\hline Ü1 & II - IV & I-II-IV \\
\hline Ü2 & I-II-III-IV-V & I-II-IV \\
\hline O1 & I-II-III-IV-V & I-II-IV \\
\hline A1 & II-III & II-III \\
\hline A2 & IV & IV \\
\hline
\end{tabular}


Ü1, dikdörtgenin tüm kritik özelliklerini biliyor olmasına rağmen üçüncü soruda yalnız prototip olarak verilen iki dikdörtgeni (II ve IV. şekiller) doğru olarak tespit edebilmiş ancak kareyi dikdörtgen olarak sınıflandıramamıştır. Öğrenci, cevabının gerekçesinin açıklanması istendiğinde şekiller üzerinde daha uzun süre düşünerek "I numaralı şekil aynı zamanda bir dikdörtgen midir?" sorusuna "Hocam tüm açıları dik, karşılıkl kenarları eş ve paralel ve karşıllkh açıları eş oluyor." ve "Evet. Çünkü (I. şekil gösterilerek) dikdörtgenin tüm özelliklerini sağlamıştı." şeklinde yanıt vermiştir. Öğrenci bu süreçte karenin açı ve kenar ölçülerini dikkate almış ve kavram kontrollü bir GM yapabilmiştir. Bu bulgulardan, öğrencinin GM sürecini başta baskın olarak şekil yönetmiş olmasına karşın üzerinde daha fazla düşünmeye zaman ayırdığında kavram kontrollü bir muhakeme yaparak ÜGM yapabildiği anlaşılmıştır.

Ü2, üçüncü soruda tüm şekillerin dikdörtgen olduğunu belirtmiştir. Gerekçe olarak da bu şekillerin dikdörtgenin özelliklerini sağlamış olduğunu öne sürmüştür. Ancak öğrencinin, söylediğinin aksine öne sürdüğü gerekçeyi şekiller üzerinde irdelemeden cevap verdiği anlaşılmıştır. Örneğin öğrenci, dikdörtgenin tüm açlarının ölçüsünün birbirine eşit olduğunu bilmesine rağmen $\mathrm{V}$. şekli de dikdörtgen olarak isimlendirmiştir. Bunun üzerine V. şeklin açılarının kontrol edilmesi istenildiğinde öğrenci açılarının ölçülerinin birbirine eşit olmadığını ifade ederek bu şeklin dikdörtgen olmadığını belirtmiştir. Bunun üzerine öğrenci (kendiliğinden) başta verdiği cevapları, “III. şeklin de bir dikdörtgen olmadığını, I. şeklin iç açı ölçülerinin ve karşılıklı kenar uzunluklarının birbirine eşit olmasından bir dikdörtgen olduğunu" ifade ederek düzeltmiştir. Ardından öğrenciye dikdörtgen hakkındaki kavramsal bilgisini sorgulamak için "Karede olup da dikdörtgende olmayan bir özellik var mıdır?" sorusu yöneltildiğinde öğrenci "dikdörtgende kenarlarn hepsi eşit değildir." yanıtını vermiştir. Buradan öğrencinin dikdörtgenin tüm kenarlarının uzunluklarının birbirine eşit olamayacağını düşündüğü, diğer bir deyişle dikdörtgen üzerinde prototip şekil etkisiyle GM yaptığı düşünülmüştür. Ancak görüşmenin devamında öğrenciye I numaralı şeklin dikdörtgen olup olmadığı sorulduğunda öğrenci bu şeklin dikdörtgen olduğunu belirtmiştir. Öğrenciye "Bu şeklin dikdörtgen olduğuna nasıl karar verdin?" sorusu yöneltildiğinde öğrenciden "Bunun karşıllklı kenarları eştir ve paraleldir ve tüm açıları eşittir." yanıtı alınmıştır. Öğrencinin verdiği yanıttan dikdörtgenin kritik özelliklerini dikkate alarak GM yaptığı anlaşılmıştır. Sonuç ola- 
rak öğrencinin verdiği cevapların gerekçelerini ortaya koyarken yaptığ GM'nin kavram kontrolünde gerçekleştiği anlaşılmıştır. Bununla beraber öğrencinin GM sürecinde şekil-kavram etkileşiminde prototip şekil etkisinin baskın olduğu ve bir takım zihinsel kırılganlıklar yaşadığı da görülmüştür.

O1, dikdörtgenin kritik özelliklerini doğru bir biçimde ifade etmesine (Karşıllklı kenarları birbirine paraleldir. İç açıları diktir.) karşın tüm şekillerin dikdörtgen olduğunu belirtmiştir. Öğrenciye V. şeklin dikdörtgenin tüm özelliklerini sağlayıp sağlamadığı sorulduğunda öğrenci bu özellikleri sağlanmadığını ifade etmiştir. Ardından öğrenci şekiller üzerinde kavram kontrollü bir GM yapmış ve 3. soruya verdiği cevapların arasından bu şeklin numarasını silmiştir. Benzer şekilde öğrenci (kendiliğinden) III numaralı şeklin de bir dikdörtgen olmadığını ifade ederek cevaplarından bu sorunun numarasını silmiştir. Elde edilen bulgulardan O1'in, ilk başta dikdörtgenin kavramsal yönünü dikkate almadan sorulara cevap verdiği, ardından kendisine yöneltilen ilave soruya yant verirken kavram kontrollü GM yaptığ1 görülmüştür. Tüm bu bulgulardan, öğrencinin dikdörtgenin kritik olan özelliklerini ifade ettiği gibi dikkate alması durumunda ÜGM gerçekleştirebildiği anlaşılmıştır.

A1, yalnız II ve III numaralı şekillerin dikdörtgen olduğunu belirtmiştir. Prototip olarak verilen IV numaralı şekil ile prototip olarak sunulmayan I numaralı şeklin dikdörtgen sınıfında olduğunu tespit edememiştir. Öğrencinin GM sürecini anlamak adına yapılan görüşmeden elde edilen bulgular aşağıda özetlenmiştir.

Öğrenci "kare, dikdörtgenin tüm özelliklerini taşır mı?" sorusunu "Evet taşır hocam." şeklinde cevaplamıştır. Yine "I numarah şekle kare demiştin. Peki, bu şekle ayn zamanda dikdörtgendir diyebilir miyiz?" sorusuna karşılık "Yok diyemeyiz hocam çünkü bunun kenar uzunluklarn eşit (kare gösterilerek) ama bununkiler (dikdörtgen gösterilerek) farklı farklı." şeklinde yanıt vermiştir. Yani öğrenci dikdörtgenin bir kenarının kısa, diğer kenarının uzun olması gerektiğini ifade ederek karenin bu özelliği sağlamamasından bir dikdörtgen olarak değerlendirilemeyeceğini öne sürmüsstür. Buradan öğrencinin GM sürecine prototip şeklin ağırlıklı olarak etki ettiği söylenebilir.

Yine öğrencinin III numaralı şeklin açlarının ölçüsünü dikkate almadan şekil hakkında karar vermiş olmasından, yürüttüğü GM sürecinin kavram kontrollü olmadığı anlaşılmıştır. Ancak bu durum öğrencinin dikdörtgen üzerine gerçekleştirdiği GM'ye prototip dikdörtgen şeklinin de kaynaklık 
etmediğini göstermektedir. Nitekim öğrencinin dikdörtgen olarak tespit ettiği III numaralı şekil bir dikdörtgen değildir. Ayrıca IV numaralı şekil prototip dikdörtgen olmasına karşın öğrenci bu şekli dikdörtgen olarak belirleyememiştir.

Tüm bu bulgulardan öğrencinin GM sürecini kısmen şekil etkisiyle yürütmeye çalışmış olsa da dikdörtgen hakkında ne kavramsal ne de şekilsel bilgiye yeterli düzeyde sahip olmadığı görülmüştür. Sonuç olarak da ÜGM yapamadığı anlaşılmıştır.

A2, dikdörtgen olarak verilen üç şekil arasından yalnız prototip olarak verilen IV numaralı şekli doğru olarak tespit edebilmiştir. A2'nin şekiller üzerinde yürüttüğü GM sürecini anlamak üzere IV numaralı şekil üzerinde karşılıklı kenar uzunluklarının eşitliği ve paralelliği sorgulandığında öğrenciden "Karşılıklı kenar uzunlukları eşittir hocam." ve "Karşıllklı kenarları birbirine paralele de benziyor hocam." şeklinde yanıt alınmıştır. Öğrencinin bu şekilden yola çıkarak kavramsal bilgisi sorgulandığında mevcut bilgisinin kısmen yeterli olduğu görülmüştür. Öğrenci mevcut bilgisini kullanarak irdelediği I. ve II. şekilleri dikdörtgen olarak değerlendirememiştir. Tüm bu bulgulardan öğrencinin GM sürecinde şekillerin kavramsal yönünü dikkate almadı$\breve{g} 1$ ve GM'sine prototip şeklin baskın olarak etki ettiği söylenebilir. Buradan da öğrencinin ÜGM gerçekleştiremediği anlaşılmıştır.

\section{Kare}

Öğrencilerin kareyle ilgili kendilerine yöneltilen beşinci ve altınc soru üzerine yürüttükleri muhakemeler neticesinde kaç numaralı şekilleri kare olarak sinıflandırdıkları Tablo 3'te verilmiştir.

Tablo 3. Öğrencilerin kareyle ilgili sorulan sorulara verdikleri yanttlar

\begin{tabular}{lll}
\hline Öğrenci & 5. Soru & 6. Soru \\
\hline Ü1 & I & I \\
\hline Ü2 & I & I \\
\hline O1 & I & I \\
\hline A1 & I-V & I-V \\
\hline A2 & I & I \\
\hline
\end{tabular}

Ü1, Ü2 ve O1'in karenin kritik özelliklerini bildikleri görülmüştür. Öğrenciler tüm şekilleri kavramsal yönden irdelemeleri sonucu yalnız I. şeklin 
kare olduğuna, diğer şekillerin de açılarına veya kenarlarına ait ölçülerin birbirinden farklı olması sebebiyle kare olmadığına karar vermiştir.

Ü1'e II. şekil gösterilerek bunun neden kare olmadığı sorulduğunda öğrenci "Ama hocam aslında karenin tüm kenarları ayn ve dik olması gerekiyor. Bunun tüm kenarları aynı değil" şeklinde cevap vermiştir. Buradan öğrencinin matematik dilini etkin olarak kullanamıor olsa da kare özelinde yeterli kavramsal bilgiye sahip olduğu ve bunu şekiller üzerindeki GM'sinde etkin olarak kullanabildiği anlaşılmıştır. Benzer şekilde Ü2 de "Ama bunların hepsi karenin özelliğini bulundurmuyor." diyerek I numaralı şeklin dışındakileri kare olarak değerlendirmemiştir. Yine O1'in de karenin kritik olan özelliklerini bildiği görülmüştür. Nitekim öğrencinin kare ile dikdörtgen arasındaki ilişki hakkında sahip olduğu anlayışın sorgulandığı bir soruda öğrenci “Ortak özellikleri bütün açıları diktir. Farkh olan özellik; karenin tüm kenarları eşit, dikdörtgenin karşıllklı kenarları eşittir." şeklinde bir açılama yapmıştır. Bu bulgulardan öğrencinin kare özelinde yürüttüğü GM'sine kavramsal bilgisinin kaynaklık ettiği anlaşılmıştır.

Kare özelinde ifade etmek gerekirse Ü1, Ü2 ve O1'in GM'lerini kavram kontrolünde gerçekleştirebildikleri, dolayısıyla ÜGM yapabildikleri anlaşılmıştır.

A1, I ve V numaralı şekilleri A2 ise yalnız I numaralı şekli kare olarak değerlendirmiştir. A1'in V numaralı şekli kare olarak değerlendirmiş olmasının gerekçesini anlamak için öncelikle kare kavramı hakkındaki bilgisinin yeterliliği anlaşılmaya çalışılmıştır. Öğrenciye "Peki I numaralı şekle neden karedir diyebiliyoruz" sorusu yöneltildiğinde öğrenci "Kenarları kısa olduğu için olabilir mi hocam?" şeklinde bir ifadeyle karşlık vermiştir. Bunun üzerine görüşme formundaki kareli zemine formda yer alan şekillerden daha kısa kenar uzunluğuna sahip olan bir dikdörtgen (komşu kenarlarının uzunluğu sirasiyla 1 br, 2 br olan) çizilerek bu şekil üzerinden öğrenciye bunun bir kare olup olmadığ 1 sorulmuştur. Öğrenci daha önce karenin kenarlarının uzunluğunun kısa olması gerektiğini ifade etmesine rağmen bu şeklin bir kare olmadığını belirtmiştir. Yani öğrencinin karşılıklı olmayan kenarlarının uzunluğu farklı olan bir dikdörtgeni kare olarak kabul etmediği görülmüştür. Bunun üzerine öğrenciye "(Karenin) Bir iç açısının ölçüsü kaç derecedir?" sorusu yöneltildiğinde öğrenci cevabı bilmediğini ifade etmiştir. Hâlbuki karenin iç açı ölçülerine ilişkin bilgi, bir dörtgenin kare olması için belirleyici olan özelliklerinden biridir. Öğrenci ile yapılan bu görüşme neticesinde kare 
hakkında kavramsal bilgisinin yeterli olmadığı anlaşılmıştır. Öğrenci, aklındaki prototip kare şekli (açlarını dikkate almadan kenarlarının uzunluğu farklı olmayan dörtgen karedir) ile formda verilen şekillerin uyumluluğunu irdeleyerek GM yapmıştır. Öğrencinin bu sebeple V numaralı şekli, kenarlarının uzunluğu birbirine eşit olmasa da yakın olmasından kare olarak kabul ettiği düşünülmüştür. Buradan öğrencinin kare özelinde ÜGM gerçekleştiremediği anlaşılmıştır.

Benzer şekilde A2'nin de kare hakkında kavramsal bilgisinin yeterli olmadığı anlaşılmıştır. Öğrenci yalnız I. şeklin kare olduğunu doğru bir şekilde tespit edebilmiş olmasına ve paralelkenarın özelliklerini (kısmen) doğru olarak bilmesine rağmen kare ile paralelkenarın hiyerarşik ilişkisini irdelerken kavramsal olarak bir değerlendirme yapmamıştır. Sonuç olarak A2 ve A1'in kare hakkındaki GM'lerinin kavram kontrolünde gerçekleşmediği anlaşılmıştır. Diğer bir deyişle bu öğrenciler ÜGM gerçekleştirememiştir.

Özetle, buraya kadar elde edilen tüm bulgulardan, üst ve orta düzey başarı gösteren öğrencilerin görüşmede verilen geometrik şekillerin hangi dörtgen ailesine mensup olduğunu tespit ederlerken bazen şekil kontrolünde olsa da çoğunlukla kavram kontrolünde GM yapabildikleri anlaşılmıştır. Özellikle öğrencilerden Ü1'in prototip şekil etkisinde GM yapma oranın diğer iki öğrenciye göre daha fazla olduğu tespit edilmiştir. Bunun yanında bu öğrencilere, verdikleri cevapların gerekçeleri sorulduğunda geometrik şekiller üzerinde daha uzun süreli düşünme fırsatı da bularak kavram kontrolünde GM yapabildikleri görülmüştür. Genel bir sonuç olarak ifade etmek gerekirse bu öğrenciler çoğunlukla ÜGM yapabilmiştir.

Alt düzey başarı gösteren öğrencilerin GM'lerindeyse çoğunlukla şekil etkisinin baskın olduğu, diğer bir ifadeyle süreçte kavram kontrolünün yeterli olmadığı görülmüştür. Bu öğrencilerin geometrik şekilleri kavramsal açıdan ele alma girişimleri de ya bilgi eksikliklerinden ya da bir takım kavram yanılgılarından kaynaklı olarak başarısız olmuştur. Buradan, öğrencilerin şekil-kavram etkileşiminde kavram kontrollü bir yönetim sergileyememelerine prototip şekil etkisinin baskınlığının ya da kavramsal bilgi eksikliğinin sebep olduğu anlaşılmıştır. Sonuç olarak bu öğrenciler ÜGM gerçekleştirememiştir. 


\section{Tartışma}

Bu bölümde, mevcut çalışmanın bulguları ile alan yazındaki ilgili çalışmaların bulguları üzerine bir tartışma yürütülmüştür.

Alan yazın incelendiğinde (farklı okul türü, sınıf düzeyi veya başarı seviyesindeki) öğrencilerin (Fischbein ve Nachlieli, 1998; Fujita, 2012; Güven ve Öztürk, 2014; Güzeller, 2018; Karpuz vd., 2014; Mariotti, 1992; Özkan ve Bal, 2017; Ubuz, 2017; Ubuz ve Üstün, 2004) ve öğretmen adaylarının (Erdoğan ve Dur, 2014; Horzum, 2018; Kozaklı Ülger ve Taban Broutin, 2017; Türnüklü, Gündoğdu Alaylı ve Akkaş, 2013) geometrik şekiller üzerindeki muhakeme süreçlerini ele alan birçok çalışmanın bulguları ile bu çalışmanın bulgularının paralellik gösterdiği anlaşılmıştır.

Karpuz vd. (2014) yaptıkları çalışmada öğrencilerin şekil içeren geometri sorularını çözmede, şekil içermeyen sorulara göre daha başarılı olduklarını ve sıklıkla prototip şekil etkisinde kaldıklarını tespit etmişlerdir. Araştırmacllar bu durumun temel sebeplerinden birinin kavramsal bilgi eksikliği ve yanlışlığı olduğunu belirtmiştir. Benzer olarak Horzum (2018) ve Türnüklü vd. (2013) de öğretmen adaylarının bazı dörtgenler için kavram bilgisi eksikliğine (örn. geometrik şekillere ilişkin yanlış ya da eksik tanım yapma, doğru tanım bilinmesine rağmen şekilleri hatalı çizme) ya da yanlışlığına sahip olmaları, Özkan ve Bal (2017) ise öğrencilerin dörtgenler hakkında kavram yanılgılarına sahip olmaları sebebiyle kavramlar üzerinde düşünürlerken prototip şekil etkisinde kaldıklarını belirtmişlerdir. Alan yazındaki çalışmaların bulgularına benzer şekilde bu çalışmada da alt düzey başarıya sahip öğrencilerin GM süreçlerinde şeklin baskın olarak etkisinin görülme sebepleri arasında öğrencilerin temel geometrik kavramlar ve dörtgenlerle alakalı kavramsal bilgi eksikliklerinin olduğu belirlenmiştir. Bu çalışmadaki öğrencilerin de (çoğunlukla alt düzey başarıya sahip olanlar) prototip şekil etkisinde kalarak GM yapma eğiliminde oldukları belirlenmiştir.

Güven ve Öztürk (2014) çalışmalarında öğrencilerin geometrik şekilleri sınıflandırırken tek bir özelliğine odaklandıklarını (kenar ya da açı), bu sebeple şeklin biçimsel özelliklerine göre karar verdiklerini belirlemişlerdir. Bu çalışmada da alt düzey başarıya sahip öğrencilerin çoğunlukla verilen dörtgenlerin açı ve kenar ölçülerinden en az birini dikkate almadan ya da yalnız prototip şekiller ile öğrencilere sunulan dörtgenlerin biçimsel olarak benzer özelliklere sahip olup olmadığına bakarak sınıflandırma yaptıkları 
belirlenmiştir. Walcott, Mohr ve Kastberg (2009) yaptıkları çalışmada, esnek prototip imajına sahip olan öğrencilerin tanıma dayalı olmayan muhakemelerinde paralelkenarla dikdörtgeni aynı olarak gördüklerini belirlemişlerdir. Bu çalışmada da üst düzey başarı gösteren bir öğrencinin verilen şekiller arasından paralelkenar olanları tespit ederken kare ve dikdörtgen olarak verilen şekillerin kenar ya da açı ölçülerini manipüle ederek paralelkenara dönüştürülebileceğini ifade etmiş olması kavram kontrolünde olmayan esnek bir prototip imajına sahip olabileceğine işaret etmektedir.

Alan yazında öğrencilerin başarı seviyesi arttıkça kavramsal bilgiye başvurma oranın arttğı (Fischbein ve Nachlieli, 1998), bununla birlikte matematikte farklı başarı seviyesine sahip her öğrencinin GM sürecinde prototip şekillerin etkisinde kalabildiği (Fujita, 2012; Ubuz ve Üstün, 2004) sonuçları ile karşılaşılmıştır. Ayrıca öğrencilerin geometrik bir şekil üzerinde şekil ile kavram ilişkisini organize ettiği muhakeme sürecinde zihinsel kırılganlıklar yaşayabileceği (Fischbein, 1993) belirtilmektedir. Bu çalışmada da akademik olarak $A 1$ ve $A 2$ 'ye göre daha başarılı oldukları tespit edilen $U \dot{U} 1$, Ü2 ve O1'in daha fazla ÜGM yapabildikleri tespit edilmiştir. Buna karşın bu öğrencilerin de zaman zaman prototip şekil etkisinde kalarak GM yaptıkları ve muhakeme sürecinde prototip şekil ile kavram arasında zihinsel gelgitler yaşadıkları tespit edilmiştir.

Özet olarak ifade etmek gerekirse, alan yazında yapılan ilgili çalışmaların bulguları ile bu çalışmanın bulgularının genel anlamda örtüştüğü söylenebilir.

\section{Sonuç}

Çalışmada elde edilen verilere ilişkin bulgular, görüşme yapılan öğrencilerin GM süreçlerini ortaya koymuştur. Öğrencilerle yapılan görüşmeler neticesinde şekil-kavram etkileşimini gerektiren durumlarda üst ve orta düzey başarıya sahip öğrencilerin çoğunlukla ÜGM gerçekleştirebildikleri belirlenmiştir. Alt düzey başarıya sahip öğrencilerinse zaman zaman kavram kontrolünde GM yapmaya çalışmış olmalarına rağmen çoğunlukla prototip şekil etkisinde kalarak GM yaptıkları tespit edilmiştir. Buradan özetle aşağıdaki sonuçlara varılmıştır:

Elde edilen bulgulardan GM sürecinde kavramsal bilgilerini baskın olarak kullanabilen Ü1, Ü2 ve O1 adlı öğrencilerin zaman zaman prototip şekil 
etkisinde kalsalar da genelde ÜGM yapabildikleri sonucuna ulaşılmıştır. Özellikle bu öğrencilerden dörtgenleri hangi gerekçelere (ölçütlere) göre sınıflandırdıklarını ortaya koymaları istendiğinde şekiller üzerindeki GM'lerini kavram kontrolünde yürütebildikleri görülmüştür. Tartışma kısmında da ifade edildiği gibi öğrenciler zaman zaman zihinsel kırılganlıklar yaşayabilirler (Fischbein, 1993). Matematik öğretmeni adayları da dâhil olmak üzere öğrencilerin dörtgenler konusunda bir takım kavramsal bilgi eksiklikleri ya da kavram yanılgıları olabilir (Horzum, 2018; Türnüklü vd., 2013). Bu durumlar göz önünde bulundurulduğunda öğrencilerin kavramsal bilgilerini destekleyecek ve etkin biçimde kullanmalarını teşvik edecek öğrenme durumları ile sürekli olarak karşılaştırılmaları gerektiği düşünülmektedir.

Ü1, Ü2 ve O1'in gerek geometrik şekillerin kritik özellikleri hakkında gerekse temel geometrik kavramlar hakkında daha önceki sınıf düzeylerinden bilgi sahibi olmaları sebebiyle bu şekillerin hiyerarşik ilişkisini öğrenmedeki hazır bulunuşluk düzeylerinin yeterli olduğu görülmüştür. Ancak A1 ve A2'nin, özellikle temel geometrik kavramlar hakkında yeterli ön bilgiye sahip olmadığ görülmüştür. Bu durumun öğrencilerin dörtgenleri sınıflandırmalarının önünde bir engel oluşturduğu görülmüştür Bu sebeple gerek bu çalışmada ele alınan dörtgenler konusunda olsun gerekse diğer geometrik şekillerin öğrenilmesinde olsun öğrencilerin geometrik şekiller üzerindeki anlayışlarının geliştirilmesi sürecinde öncelikle ön koşul kavramlarda hazır bulunuşluk düzeylerinin yeterli olması için çaba sarf edilmesi gerektiği sonucuna ulaşılmıştır.

A1 ve A2'nin GM süreçlerinde kavramsal bilgiyi kullanmamalarının (ya da kullanamamalarının) sebebi bu sınıf düzeyine kadar şekillerin çok fazla prototiplerine maruz kalmış olmaları olabilir. Karpuz vd. (2014) öğretmenlerin öğrenme-öğretme sürecinde geometrik şekillerin sıklıkla standart çizimlerini kullanmalarının, öğrencilerin bu şekilleri model olarak kabul etmelerine neden olduğunu ifade etmektedirler. Bu sebeple özellikle geometrik şekillerin kavramsal yönüne dikkat etmeyen öğrencilerin sıklıkla prototip dışı örneklere de maruz kalmaları ve bu şekiller üzerinde kavram kontrollü GM yapmalarının teşvik edilmesi gerektiği söylenebilir. 


\title{
EXTENDED ABSTRACT
}

\section{6th Grade Students' Geometrical Reasoning Processes About Quadrilaterals}

\author{
Ahmet Mutluoğlu - Ahmet Erdoğan \\ Ministry of National Education, Necmettin Erbakan University
}

As in other branches of mathematics, students have different thinking styles and different levels of understanding in geometry (Baki, 2018). However, all individuals have the potential to develop thinking and reasoning skills in the context of geometry (Van De Walle, Karp and Bay-Williams, 2012). Looking at many studies on learning and teaching geometry, it is seen that the emphasis on the nature of geometrical reasoning (GR) and how it can be improved (Güven and Karpuz, 2016; Jones, 1998; Karpuz, Koparan and Güven, 2014). One of these studies is the Theory of Figural Concepts (Fischbein, 1993).

According to this theory, geometrical shapes are mental entities that have both conceptual and figural characters simultaneously. For example, any triangle drawn on a plane represents the mental image (shape) as a figure, but it also represents the concept in terms of its features (for instance, the sum of the internal angle measurements is 180 degrees.). For this reason, Fischbein (1993) stated that geometrical shapes form a third category called 'figural concepts'. According to this theory, geometrical reasoning (GR) is related to the nature of the concept-figure relationship. Ideally, the component that should control the meanings, relationships and features of the figure should be the concept (Fischbein, 1993). This is considered as high level reasoning (HGR) in the GM process. However, there may be cases where the figure dominates the concept during the reasoning process. For example, even if a student knows the definition of a rectangle, he/she will not be able to determine the hierarchical relationship between the two by looking only at the appearance of the square (Fischbein, 1993).

The development of figural concept is not usually a natural process. For this reason, one of the main tasks of mathematics education (in the branch of 
geometry) is to create teaching situations that will ensure close cooperation between the two aspects of geometric shape until it becomes a unitary mental object (Fischbein, 1993). The aim of this study is to examine the current GR processes of students on quadrilaterals in the context of "The Theory of Figural Concepts". For this purpose, the answer to the problem sentence "How are the geometrical reasoning processes of the students about parallelogram, rectangle and square concepts? was sought.

In this study, case study methods, which is one of the qualitative research designs, were used. The study group of the research consists of 6 students in the 6th grade of a secondary school located in Kulu district center in Konya in 2016-2017 academic year. These students were divided into three levels (two high level [H1 and H2], two moderate [M1 and M2] and two lower level [L1 and L2]) according to their mathematics achievement. The data of the study was obtained from semi-structured interviews with students. However, M2 was excluded from the study group because the data obtained from the interview with him was not sufficient and appropriate to analyze his GR process. The obtained data were analyzed with descriptive analysis.

According to the findings of the study, while determining which quadrilateral family of geometric shapes belong to, it is understood that $\mathrm{H} 1, \mathrm{H} 2$ and M1 can mostly perform GR in conceptual control, although sometimes in figural control. Particularly, it was found that the rate of performing GR under prototype shape of H1 was higher than the other two students. In addition, when asked the reasons for their answers, it was seen that these students had the opportunity to think on geometric shapes for a longer time and they could perform GR in concept control. As a general conclusion, these students were mostly able to perform HGR. In the GR processes of L1 and L2, shape effect is dominant, in other words, concept control is not sufficient in the process. These students' attempts to conceptually deal with geometric shapes have also failed due to either lack of knowledge or misconceptions. From this, it was understood that the dominance of prototype shape effect or lack of conceptual knowledge caused students' inability to provide concept control over shapes in figure-concept interaction. As a result, these students could not perform HGR.

When the literature is examined, it is understood that the findings of many studies dealing with the reasoning processes on geometric shapes are 
parallel with the findings of this study. For example, Karpuz et al. (2014) found that students were more successful in solving shape-containing geometry questions compared to non-shape questions and often were affected by prototype shape. In some studies, it is stated that pre-service teachers are affected by prototype shape when they think on concepts due to incomplete or incorrect conceptual knowledge about some quadrilaterals (Horzum, 2018; Türnüklü et al., 2013). Similar to the findings of the studies in the literature, it was determined in this study that the dominant effect of the figure in the GR processes of the students with lower level success was the lack of conceptual knowledge about basic geometric concepts and quadrilaterals.

Güven and Öztürk (2014) found that students focused on a single feature (edge or angle) while classifying geometric shapes, and therefore they decided according to the figural characteristics of the shape. In the literature, it was found that the rate of applying to conceptual information increased as the success level of the students increased (Fischbein and Nachlieli, 1998), however, it was found that every student with different success levels in mathematics could be affected by prototype shapes in GR process (Fujita, 2012; Ubuz and Üstün, 2004). In addition, it is stated that students may experience mental fragilities during the reasoning process in which they organize the relationship between figure and concept on a geometric shape (Fischbein, 1993). In this study, it was also found that H1, H2 and M1, which were found to be more successful than L1 and L2, could perform more HGR. On the other hand, it was found that these students also performed GR by the effect of prototype shape and experience mental fragilities between prototype shape and concept during the reasoning process.

From the discussion on the findings of the studies in the literature with this study, it has been concluded that students should be constantly encountered with learning situations that will support their conceptual knowledge and encourage them to use this information effectively on all geometric shapes (prototypes or non-prototypes) during the GM process. In addition, it was seen that in the process of developing students' understanding of geometric shapes, first of all, efforts should be made in order to have sufficient level of readiness in prerequisite concepts.

\section{Kaynakça / References}

Altun, M. (2007). Liselerde matematik eğitimi. Bursa: Alfa Aktüel Yayınları. 
Baki, A. (2018). Matematiği öğretme bilgisi. (1. bs.). Ankara: Pegem Akademi.

Breyfogle, M. L. ve Lynch, C. M. (2010). Van Hiele revisited. Mathematics Teaching in the Middle School, 16(4), 232-238. doi:10.2307/41183561

Büyüköztürk, Ş., Çakmak, E. K., Akgün, Ö. E., Karadeniz, Ş. ve Demirel, F. (2017). Bilimsel araştırma yöntemleri (23. bs.). Pegem Akademi Yayıncılık.

Erdogan, A. (2017a). Examining pre-service mathematics teachers' conceptual structures about" geometry. Journal of Education and Practice, 8(27), 65-74.

Erdogan, A. (2017b). Investigation of mathematics teacher candidates' conceptual structures about "measurement" through word association test: the example of Turkey. Journal of Education and Training Studies, 5(12), 162173.

Erdoğan, E. Ö. ve Dur, Z. (2014). Preservice mathematics teachers' personal figural concepts and classifications about quadrilaterals. Australian Journal of Teacher Education, 39(6), 107-133. doi:10.14221/ajte.2014v39n6.1

Ersoy, Y. (2006). İlköğretim matematik öğretim programındaki yenilikler-I: Amaç, içerik ve kazanimlar. The Turkish Online Journal of Educational Technology, 5(1), 30-44.

Fischbein, E. (1993). The theory of figural concepts. Educational Studies in Mathematics, 24(2), 139-162. doi:10.1007/BF01273689

Fischbein, E. ve Nachlieli, T. (1998). Concepts and figures in geometrical reasoning. International Journal of Science Education, 20(10), 1193-1211. doi:10.1080/0950069980201003

Fujita, T. (2012). Learners' level of understanding of the inclusion relations of quadrilaterals and prototype phenomenon. Journal of Mathematical Behavior, 31(1), 60-72. doi:10.1016/j.jmathb.2011.08.003

Gülkılık, H. (2013). Matematiksel anlamada temsillerin rolü: Sanal ve fiziksel manipülatifler. Yayımlanmamış doktora tezi. Gazi Üniversitesi, Eğitim Bilimleri Enstitüsü, Ankara.

Güven, B. ve Karpuz, Y. (2016). Geometrik muhakeme: Bilişsel perspektifler. E. Bingölbali, S. Arslan ve İ. Ö. Zembat (Ed.), Matematik Ĕgitiminde Toeriler içinde (1. bs., s. 245-264). Ankara: Pegem Akademi Yayıncılık.

Güven B. ve Öztürk T.. (2014). Öğrencilerin özel dörtgenler ile ilgili anlamalarının şekilsel kavram teorisi kapsamında değerlendirilmesi. XI. Ulusal Fen ve Matematik Eğitimi Kongresi, ADANA, TÜRKIYYE, 11-14 Eylül 2014, 9394. 
Güzeller, G. (2018). 5 ve 6. simf öğrencilerinin şekilsel kavram teorisi çerçevesinde temel geometrik kavramlar anlamlandırmasinn incelenmesi. Yayımlanmamış yüksek lisans tezi.Hacettepe Üniversitesi, Eğitim Bilimleri Enstitüsü,Ankara.

Horzum, T. (2018). Matematik öğretmeni adaylarının dörtgenler hakkındaki anlamalarının kavram haritası aracilığıyla incelenmesi. Turkish Journal of Computer and Mathematics Education, 9(1), 1-30. doi:10.16949/turkbilmat.333678

Jones, K. (1998). Theoretical frameworks for the learning of geometrical reasoning. Proceedings of the British Society for Research into Learning Mathematics, $18(1,2), 29-34$.

Karpuz, Y. (2018). Duval'in bilişsel modeline uygun tasarlanan öğrenme ortammın değerlendirilmesi. Yayımlanmamış doktora tezi. Karadeniz Teknik Üniversitesi, Eğitim Bilimleri Enstitüsü, Trabzon.

Karpuz, Y., Koparan, T. ve Güven, B. (2014). Geometride öğrencilerin şekil ve kavram bilgisi kullanım. Turkish Journal of Computer and Mathematics Education, 5(2), 108-118.

Kozaklı Ülger, T. ve Taban Broutin, M. S. (2017). Pre-service mathematics teachers' understanding of quadrilaterals and the internal relationships between quadrilaterals: The case of parallelograms. European Journal of Educational Research, 6(3), 331-345. doi:10.12973/eu-jer.6.3.331

Mariotti, M. A. (1992). Geometrical reasoning as a dialectic between the figural and the conceptual aspects. Topologie Structurale, 18.

Mariotti, M. A. ve Fischbein, E. (1997). Defining in classroom activities. Educational Studies in Mathematics, 34(3), 219-248. doi:10.1023/A:1002985109323

MEB (2009). Illköğretim matematik dersi 6-8. sinıflar öğretim programı. Ankara: MEB.

MEB (2013). Ortaokul matematik dersi (5, 6, 7 ve 8. sinflar) öğretim programı. Ankara: MEB

MEB (2018). Ortaokul Matematik dersi (1, 2, 3, 4, 5, 6, 7 ve 8. sinflar) öğretim programi. Ankara: MEB

Miles, M, B. ve Huberman, A. M. (1994). Qualitative data analysis: An expanded Sourcebook. (2. ed.). Thousand Oaks, CA: Sage.

NCTM. (2012). Statement of Beliefs. 01 Şubat 2019 tarihinde http://www.nctm.org/beliefs.aspx. adresinden erişildi

Olivera, Đ. ve Zeljić, M. (2017). Theoretical frameworks of development geometrical thinking according to Van Hiele, Fischbein and HoudementKuzniak. TEME, XLI(3), 623. doi:10.22190/TEME1703623D 
Olkun, S. ve Uçar, Z. T. (2014). İlköğretimde etkinlik temelli matematik öğretimi. Eğiten Kitap.

Özkan, M. ve Bal, A. P. (2017). Analysis of the misconceptions of 7th grade students on polygons and specific quadrilaterals. Eurasian Journal of Educational Research, 17(67), 161-182. doi:10.14689/ejer.2017.67.10

Paksu Duatepe, A. (2016). Van Hiele geometrik düşünme düzeyleri. E. Bingölbali, S. Arslan ve I. Ö. Zembat (Ed.), Matematik Ĕ̆itiminde Toeriler içinde (1. bs., s. 265-276). Ankara: Pegem Akademi Yayıncılık.

Türnüklü, E. (2014). Dörtgenlerde aile ilişkilerinin yapılandırılması: İlköğretim matematik öğretmen adaylarının ders planlarının analizi. Egitim ve Bilim, 39(173), 197-208.

Türnüklü, E., Gündoğdu Alayli, F. ve Akkaş, E. N. (2013). Investigation of prospective primary mathematics teachers' perceptions and images for quadrilaterals. Kuram ve Uygulamada Egitim Bilimleri, 13(2), 1225-1232.

Ubuz, B. (2017). Dörtgenler arasındaki ilişkiler: 7. sınıf öğrencilerinin kavram imajları. Yaşadıkça Ĕ̆itim Dergisi, 31(1), 55-68.

Ubuz, B. ve Üstün, I. (2004). Figural and conceptual aspects in defining and identifying polygons. Eurasian Journal of Educational Research, 16, 15-26.

Van De Walle, J. A., Karp, K. S. ve Bay-Williams, J. M. (2012). Ilkokul ve ortaokul matematiğ̌: Gelişımsel yaklaşımla ögřetim. (S. Durmuş, Ed.). Ankara: Nobel Akademik Yayıncilık.

Walcott, C., Mohr, D. ve Kastberg, S. E. (2009). Making sense of shape: An analysis of children's written responses. Journal of Mathematical Behavior, 28(1), 30-40. doi:10.1016/j.jmathb.2009.04.001

Yenilmez, K. ve Yaşa, E. (2008). İlköğretim öğrencilerinin geometrideki kavram yanılgıları. Uludă̆ Üniversitesi Eğitim Fakültesi Dergisi, 21(2), 461-483.

Yıldırım, A. ve Şı̇ssek, H. (2008). Sosyal bilimlerde nitel araștırma yoütemleri (6. bs.). Seçkin Yayıncılık.

\section{Kaynakça Bilgisi / Citation Information}

Mutluoğlu, A. ve Erdoğan, A. (2020). 6. sinıf öğrencilerinin dörtgenler hakkındaki geometrik muhakeme süreçleri. OPUS-Uluslararası Toplum Araştırmaları Dergisi, 16(27), 236-265. DOI: 10.26466/opus.673833 